\title{
Correction: systematic review: do patient expectations influence treatment outcomes in total knee and total hip arthroplasty?
}

Tsjitske M Haanstra*, Tobias van den Berg, Raymond W Ostelo, Rudolf W Poolman, Elise P Jansma, Pim Cuijpers and Henrica C W de Vet

\section{Correction}

After publication of this article, it came to our attention that an author's name was misspelled. The correct name is Elise P Jansma.

The authors and Publisher apologize to the readers for the inconvenience caused.

Received: 18 April 2013 Accepted: 18 April 2013

Published: 29 April 2013

\section{Reference}

Haanstra TM, van den Berg T, Ostelo RW, Poolman RW, Jansma IP, Cuijpers P, de Vet HCW: Systematic review: do patient expectations influence treatment outcomes in total knee and total hip arthroplasty? Health Quality Life Outcomes 2012, 10:152. 18 December 2012

\section{doi:10.1186/1477-7525-11-72}

Cite this article as: Haanstra et al:: Correction: systematic review: do patient expectations influence treatment outcomes in total knee and total hip arthroplasty?. Health and Quality of Life Outcomes 2013 11:72.

\footnotetext{
*Correspondence: thaanstra@vumc.nl

Department of Epidemiology and Biostatistics and the EMGO Institute for Health and Care Research, VU University Medical Centre Amsterdam, Van der
} Boechorststraat 7, 1081 BT, Amsterdam, the Netherlands

Submit your next manuscript to BioMed Central and take full advantage of:

- Convenient online submission

- Thorough peer review

- No space constraints or color figure charges

- Immediate publication on acceptance

- Inclusion in PubMed, CAS, Scopus and Google Scholar

- Research which is freely available for redistribution 